DOE/NASA/50306-9

NASA TM-107183

PECEPVE

CONF-960457 - - 7

MAY 13 MOSO

OSTI

\title{
The Effect of Counterface on the Tribological Performance of a High Temperature Solid Lubricant Composite From 25 to $650{ }^{\circ} \mathrm{C}$
}

Christopher DellaCorte

National Aeronautics and Space Administration

Lewis Research Center

Work performed for

U.S. DEPARTMENT OF ENERGY

Conservation and Renewable Energy

Office of Vehicle and Engine R\&D

Prepared for the

International Conference on Metallurgical Coatings and Thin Films sponsored by the American Vacuum Society

San Diego, California, April 22-26, 1996 
This report has been reproduced directly from the best available copy.

Available to DOE and DOE contractors from the Office of Scientific and Technicai inivimaticr., P.O. Box 62, Oak Ridge. TN 37831; prices available from (615) 576-8401, FTS 626-8401.

Available to the public from the National Technical information Service, U.S. Department of Commerce, 5285 Port Royal Rd., Springfield, VA 22161.

This report was prepared as an account of work sponsored by an agency of the United States Government. Neither the United States Government nor any agency thereot, nor any of their employees, makes any warranty, express or implied, or assumes any legal liability or responsibility for the accuracy, comploteness, or usefulness of any information, apparatus, product, or process disclosed, or represents that its use would not infringe privately owned rights. Reference herein to any specific commercial product, process, or senvice by trade name, trademark, manufacturer, or otherwise, does not necessarily constitute or imply its endorsement, recommendation, or favoring by the United States Government or any agency thereof. The views and opinions of authors expressed herein do not necessarily state or reflect those of the United States Government or any agency thereof. 
DOE/NASA/50306-9

NASA TM-107183

\section{The Effect of Counterface on the Tribological Performance of a High Temperature Solid Lubricant Composite From 25 to $650^{\circ} \mathrm{C}$}

Christopher DellaCorte

National Aeronautics and Space Administration

Lewis Research Center

Cleveland, Ohio 44135

Work performed for

U.S. DEPARTMENT OF ENERGY

Conservation and Renewable Energy

Office of Vehicle and Engine R\&D

Washington, D.C. 20545

Under Interagency Agreement DE-AI01-91CE50306

Prepared for the

International Conference on Metallurgical Coatings and Thin Films sponsored by the American Vacuum Society

San Diego, California, April 22-26, 1996

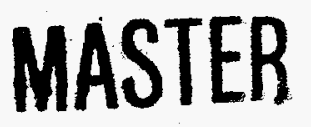

DISTRIBUTION OF THIS DOCUMENT IS UNLMITED $/ Q$ 


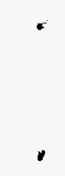

$1724:$ 


\title{
THE EFFECT OF COUNTERFACE ON THE TRIBOLOGICAL PERFORMANCE OF A HIGH
}

\author{
TEMPERATURE SOLID LUBRICANT COMPOSITE FROM 25 TO $650^{\circ} \mathrm{C}$
}

\author{
Christopher DellaCorte \\ National Aeronautics and Space Administration \\ Lewis Research Center \\ Cleveland, Ohio 44135
}

\section{SUMMARY}

The effect of counterface selection on the tribological performance of a $\mathrm{Ag} / \mathrm{BaF} \mathrm{F}_{2}-\mathrm{CaF}_{2}$ containing composite coating is studied. Ceramic $\left(\mathrm{Al}_{2} \mathrm{O}_{3}\right)$ and metal (Inconel X-750) pins are slid against PS300 (a metal bonded chrome oxide coating with $\mathrm{Ag}$ and $\mathrm{BaF}_{2} / \mathrm{CaF}_{2}$ lubricant additives) in a pin-on-disk tribometer at 25500 and $650^{\circ} \mathrm{C}$.

Compared to the ceramic counterface, the metal counterface generally exhibited lower friction and wear at $25^{\circ} \mathrm{C}$ but higher friction and wear at $650^{\circ} \mathrm{C}$. Friction coefficients, for example, for the $\mathrm{Al}_{2} \mathrm{O}_{3} / \mathrm{PS} 300$ combination at $25^{\circ} \mathrm{C}$ were 0.64 compared to 0.23 for the Inconel/PS300 sliding couple. At $650{ }^{\circ} \mathrm{C}$ the ranking was reversed. The $\mathrm{Al}_{2} \mathrm{O}_{3} / \mathrm{PS} 300$ combination gave a friction coefficient of 0.19 while the friction for the metal counterface increased slightly to about 0.3 . Based upon these tribological results and other information found in the literature, it appears that the performance of each counterface/PS 300 combination is affected by the ability of the solid lubricant additives to form an adequate transfer film. The effects of surface wettability and tribological compatibility are discussed in relation to the observed tribological results.

\section{INTRODUCTION}

High temperature lubrication presents a significant challenge to the tribology community (refs. 1 and 2). At temperatures above $350^{\circ} \mathrm{C}$, conventional liquid lubricants and most conventional solid lubricants (e.g. graphite and $\mathrm{MoS}_{2}$ ) begin to degrade (ref. 3). Under these circumstances, advanced solid lubricants must be employed. Soft noble metals $(\mathrm{Au}, \mathrm{Ag}, \mathrm{Pt})$, inorganic fluorides $\left(\mathrm{LiF}, \mathrm{CaF}_{2}, \mathrm{BaF}_{2}\right)$ and some metal oxides $\left(\mathrm{NiO}, \mathrm{MoO}_{3}\right.$ ) have been successfully employed as solid lubricants (ref. 4). These materials generally possess stable thermochemistry at elevated temperatures as well as low shear strength properties which make them good solid lubricants.

An often overlooked aspect of solid lubrication is the selection of an appropriate counterface. To function as an effective solid lubricant a material must not only possess good thermochemical stability and low shear but must be able to form a transfer film on the sliding counterface in order to reduce friction and wear. Transfer film formation is affected by adhesion and wettability of the lubricants to the counterface. These characteristics are sometimes referred to as tribological compatibility (ref. 5).

In this paper, the effect of counterface selection on the performance of solid lubricants will be studied by examining the tribological properties of a $\mathrm{Ag} / \mathrm{BaF}_{2}-\mathrm{CaF}_{2}$ composite in sliding against metal and ceramic counterfaces using a pin-on-disk tribometer. In addition to comparing tribological behavior, wear surface morphology will be observed using optical and electron micrographic techniques. The tribological performance will be considered in the context of relevant research cited in the literature.

\section{MATERIALS}

The tribological materials studied include either $\mathrm{Al}_{2} \mathrm{O}_{3}$ or Inconel X-750 pins in sliding against a disk coated with a composite coating. The composite coating studied is designated PS300. PS300 is a plasma sprayed nichrome bonded $\mathrm{Cr}_{2} \mathrm{O}_{3}$ coating with silver and $\mathrm{BaF}_{2} / \mathrm{CaF}_{2}$ eutectic solid lubricant additions (ref. 6). This coating is a follow-on or next generation composition to PS200, a chrome-carbide based coating which has been shown to provide good tribological performance at temperatures as high as $900{ }^{\circ} \mathrm{C}$ (refs. 7 and 8 ). Several key benefits are realized by basing the coating composition on chrome oxide rather than chrome carbide. Unlike chrome carbide, which because of its extreme hardness requires diamond grinding, 
chrome oxide is readily machinable by low cost carbide grinding techniques. Furthermore, chrome oxide is a known high temperature lubricant which cannot further oxidize upon exposure to high temperature air (ref. 9).

Silver is added as the low temperature solid lubricant. It has been used to lubricate bearings, seals, fasteners and other components and exhibits good thermochemical stability over a wide temperature range (ref. 10).

$\mathrm{BaF}_{2} / \mathrm{CaF}_{2}$ eutectic is added as the high temperature solid lubricant. The fluoride eutectic undergoes a brittle to ductile transition at about $400{ }^{\circ} \mathrm{C}$ resulting in a reduction in shear strength; increasing its effectiveness as a lubricant (refs. 11 and 12)

Sliney pioneered the combination of silver and fluorides in composite coatings three decades ago as a way to provide reduced friction and wear from 25 to $650{ }^{\circ} \mathrm{C}$ over repeated temperature cycling (ref. 13). The PS300 coating is an extension to this concept.

\section{Coating Preparation}

The coating composition of PS300 is as follows: $60 \mathrm{wt} \% \mathrm{Cr}_{2} \mathrm{O}_{3}, 20 \mathrm{wt} \% \mathrm{NiCr}(80 / 20)$ binder, $10 \mathrm{wt} \%$ silver and $10 \mathrm{wt} \% \mathrm{BaF}_{2} / \mathrm{CaF}_{2}$ eutectic. More complete details and volumetric composition figures are given in Table I. The coatings were prepared by plasma spraying a simple powder blend of the constituents onto superalloy test disks which have been pre-coated with a $0.1 \mathrm{~mm}$ thick nichrome $(80 / 20)$ bond coat. Table II shows the plasma spray parameters used to apply the coatings which were deposited in multiple passes until a thickness of $0.5 \mathrm{~mm}$ was achieved. Figure 1 shows cross-section micrographs of the PS300 coating. Following deposition, the coatings were ground to a final thickness (PS300 $+\mathrm{NiCr}$ bond coat) of $0.5 \mathrm{~mm}$. Air atomized water spray was used as the grinding coolant/lubricant to prevent surface contamination with oil. The ground surface roughness was typically about $0.5 \mathrm{~mm}$ rms. 600 grit $\mathrm{SiC}$ abrasive paper was used to lightly hand polish the coating surface to a finish of 0.1 to $0.2 \mathrm{~mm}$ rms.

\section{Counterface Materials}

One metal (Inconel X-750) and one ceramic $\left(\mathrm{Al}_{2} \mathrm{O}_{3}\right)$ were tested as pins in sliding against the PS300 coated disks in this study. Inconel X-750 is a nickel based superalloy with excellent high temperature strength, toughness and oxidative stability. $\mathrm{Al}_{2} \mathrm{O}_{3}$ is a well known wear resistant ceramic which has been shown to perform well as a high temperature tribological material (refs. 14 and 15).

The Inconel pins are machined from precipitation hardened $9.5 \mathrm{~mm}$ diameter rod. The pins are $25 \mathrm{~mm}$ long and hemispherically tipped with a $25.4 \mathrm{~mm}$ radius of curvature. The pin hardness is RC32-36.

The $\mathrm{Al}_{2} \mathrm{O}_{3}$ pins are prepared by diamond grinding a $25.4 \mathrm{~mm}$ radius of curvature on the end of sintered rod stock $9.5 \mathrm{~mm}$ in diameter. The material is 99.4 percent pure, fully densified alumina. Table III gives its properties as supplied by the manufacturer. The pin surfaces were polished to less than $0.2 \mathrm{~mm} \mathrm{rms}$ surface roughness.

Prior to testing, the pins and disks were rinsed with pure ethyl alcohol, scrubbed with a paste of levigated $\mathrm{Al}_{2} \mathrm{O}_{3}$ powder and water, rinsed with deionized water and air dried.

\section{Tribological Testing}

The specimens are tested in a pin-on-disk test rig described in detail in reference 16 and shown in figure 2. The pin wears a $51 \mathrm{~mm}$ diameter track into the rotating test disk which is inductively heated to the desired test temperature. The air atmosphere is controlled and maintained at 50 percent R.H. at $25^{\circ} \mathrm{C}$.

Selected test temperatures were 25500 and $650^{\circ} \mathrm{C}$. Test velocity was $370 \mathrm{rpm}(1 \mathrm{~m} / \mathrm{s})$ and the load was 4.91N. These conditions were chosen to simulate foil air bearings which experience sliding contact during low journal rotation speeds during start-up/shut-down conditions.

Friction was monitored continuously during the test which typically lasts $30 \mathrm{~min}$. Wear was measured using optical microscopy (for pin wear scars) and stylus surface profilometry. At least six tests were conducted for each test condition. Data uncertainties presented are one standard deviation. The tribological data for the Inconel/PS300 combination have recently been reported in reference 6 and have been incorporated in this paper for comparative purposes. 


\section{RESULTS AND DISCUSSION}

The friction and wear results are summarized in Table IV and shown graphically in figures 3 to 5. When sliding against the metal, Inconel X-750, friction and coating wear increase markedly with test temperature. Pin wear factors fluctuated but were about the same at $25^{\circ} \mathrm{C}$ as at $650^{\circ} \mathrm{C} ; \approx 3 \times 10^{-5} \mathrm{~mm}^{3} / \mathrm{N}-\mathrm{m}$. Disk coating wear factors increased an order of magnitude over this temperature range from $6.6 \times 10^{-5} \mathrm{~mm}^{3} / \mathrm{N}-\mathrm{m}$ at $25^{\circ} \mathrm{C}$ to $7.1 \times 10^{-4} \mathrm{~mm}^{3} / \mathrm{N}-\mathrm{m}$ at $650^{\circ} \mathrm{C}$. Friction at $25^{\circ} \mathrm{C}$ was low, 0.23 , and increased to a moderate value of 0.31 at $650^{\circ} \mathrm{C}$.

When sliding against the ceramic, $\mathrm{Al}_{2} \mathrm{O}_{3}$, friction and wear of both the ceramic pin and the coating decreased with test temperature. For example, at $25^{\circ} \mathrm{C}$, the friction coefficient was quite high at 0.62 . Friction dropped by a factor of two to 0.32 at $500^{\circ} \mathrm{C}$ and was further reduced to 0.19 at $650{ }^{\circ} \mathrm{C}$. Wear factors for both the pin and disk coating followed the same trend. At elevated temperatures, pin wear decreased over an order of magnitude from $10^{-6}$ to $10^{-7} \mathrm{~mm}^{3} / \mathrm{N}-\mathrm{m}$ compared to room temperature. Disk wear factors, which were $2.3 \times 10^{-4} \mathrm{~mm}^{3} / \mathrm{N}-\mathrm{m}$ at $25^{\circ} \mathrm{C}$ were reduced to $2.5 \times 10^{-5} \mathrm{~mm}^{3} / \mathrm{N}-\mathrm{m}$ at $500^{\circ} \mathrm{C}$ and $7.8 \times 10^{-6} \mathrm{~mm}^{3} / \mathrm{N}-\mathrm{m}$ at $650{ }^{\circ} \mathrm{C}$.

Clearly, the trend of friction and wear was reversed for $\mathrm{Al}_{2} \mathrm{O}_{3}$ sliding against the composite coatings. Previous research experience by the author with the solid lubricants used in PS300 and relevant information from the literature offer some plausible explanations for the tribological behavior observed.

For instance, at room temperature, the alumina pin was poorly lubricated by the PS300 coating as evidenced by very high friction. In sharp contrast, the Inconel pin exhibited low friction in sliding against the coating under identical test conditions. This may be due to the inability of the silver in PS300 to form an adequate transfer film on the ceramic pin surface needed to reduce friction.

In research conducted by Erdemir et al. (ref. 14), silver was used to lubricate $\mathrm{Al}_{2} \mathrm{O}_{3}$. In their work, to achieve sufficient adhesion and reduce friction, it was necessary to apply $\mathrm{Ag}$ to the $\mathrm{Al}_{2} \mathrm{O}_{3}$ surface using Ion Beam Assisted Deposition (IBAD). Their coating provided lubrication at room temperature. At elevated temperatures, however, the silver spontaneously dewetted the $\mathrm{Al}_{2} \mathrm{O}_{3}$ surface.

Subsequent work conducted by the author showed a similar result (ref. 17). Silver was unsuccessful as a lubricant for $\mathrm{Al}_{2} \mathrm{O}_{3}$ unless an active metal (Ti) bond layer was sputter deposited between the $\mathrm{Al}_{2} \mathrm{O}_{3}$ and the silver to promote adhesion. Without the bond layer, the silver coating rapidly delaminated causing friction levels to rise to 0.7 , approximately equal to that measured in the present study for the $\mathrm{Al}_{2} \mathrm{O}_{3} / \mathrm{PS} 300$ combination.

The inability of silver to transfer from the PS300 coating and adhere to the $\mathrm{Al}_{2} \mathrm{O}_{3}$ counterface may be the reason for the high friction observed. Since silver is the only material in the composite with low temperature lubrication properties (i.e. low shear strength), the friction is high. Clauss writes that obtaining good adhesion of soft metals is a major problem and that oxide films on metals reduce adhesion and film life (ref. 4). Clearly, silver is not a functional lubricant for $\mathrm{Al}_{2} \mathrm{O}_{3}$ unless effective measures are taken to improve transfer film formation and adhesion. SEM/EDS analyses of $\mathrm{Al}_{2} \mathrm{O}_{3}$ pin surfaces after sliding against the coating at $25^{\circ} \mathrm{C}$ exhibit only small localized pockets of wear debris containing essentially all the components of PS300. No lubricant-like film is detected. Serendipitous $\mathrm{Ag}$ film formation on $\mathrm{Al}_{2} \mathrm{O}_{3}$ when sliding against PS300 obviously does not occur; helping to explain the poor room temperature performance of the $\mathrm{Al}_{2} \mathrm{O}_{3} / \mathrm{PS} 300$ combination.

The situation was reversed when sliding against Inconel pins. At $25^{\circ} \mathrm{C}$, sliding friction is low and post test surface analyses using SEM/EDS show a more or less uniform layer of silver (and some fluorides). This behavior is very similar to results published in reference 16 . In this work, transfer films of silver formed on a chromium-cobalt alloy pin in sliding against a carbide composite coating which also contained silver and $\mathrm{BaF}_{2} / \mathrm{CaF}_{2}$ eutectic as its lubricants.

Silver alone has been shown by Bowden and Tabor to be an effective lubricant for Inconel X-750 in a ball-on-flat geometry (ref. 18). In their work, friction coefficients of 0.1 to 0.4 were obtained using silver films to lubricate the sliding contact.

In related applications, silver films are used to lubricate rolling element bearings used for $x$-ray tubes (ref. 4). In this case, the bearings are made from $440 \mathrm{C}$ stainless steel and operate in a vacuum from 25 to $600{ }^{\circ} \mathrm{C}$. Despite the development of this lubrication method some five decades ago (ref. 19), the use of silver films, now applied by ion-plating, persist in this application.

Additionally, silver is used throughout the aircraft and turbine industry as an antiseize and thread lubricant for superalloy fasteners (ref. 20). In this case, good adhesion under high contact stresses is essential. There is concern about silver sulphide/sulfuric acid, formed through a reaction of the silver with sulphur found in fuel, attacking fasteners and turbine components but no significantly improved lubricants have yet been identified. 
Clearly, the results from the experimental work presented here as well as those reviewed from the literature show that silver is a suitable lubricant for Inconel, but not for $\mathrm{Al}_{2} \mathrm{O}_{3}$. This tribological "compatibility" helps to explain the dramatic difference in the triboperformance between the metal and ceramic counterface.

The tribological characteristics and performance are somewhat reversed when the test temperature is increased. In fact, the lowest friction, pin wear factor and disk wear factors are measured for the $\mathrm{Al}_{2} \mathrm{O}_{3}$ pins sliding against the PS300 coating at $650^{\circ} \mathrm{C}$. To understand this behavior it is useful, once again, to consider the counterface/lubricant compatibility.

The high temperature lubricant in $\mathrm{PS} 300$ is $\mathrm{BaF}_{2} / \mathrm{CaF}_{2}$ eutectic. $\mathrm{BaF}_{2} / \mathrm{CaF}_{2}$ eutectic has been shown to be a good solid lubricant above $400{ }^{\circ} \mathrm{C}$ as a thin film coating (ref. 13) and as a component in composites (refs. 16, 21, and 22). The fluoride eutectic functions by providing a low shear strength film between the sliding surfaces to mitigate friction and wear.

Sliney's early work with fluorides centered on thin, fused coatings deposited on nickel and cobalt based superalloys (refs. 23 and 13). These coatings were adherent and provided adequate life for limited sliding applications. Later work on composites offer more insight towards understanding the tribological performance of the PS300/ $\mathrm{Al}_{2} \mathrm{O}_{3}$-Inconel sliding couples.

Sliney briefly conducted research on composites formed by infiltrating a porous Inconel composite with fluorides (ref. 24). In that work, he noted that when vacuum infiltration of the porous metal shell with molten fluorides was attempted, poor infiltration was exhibited if the metal (Inconel) matrix was bright, clean and free from surface oxides. If the matrix was lightly preoxidized, surface wetting of the fluorides occurred producing a strong "wicking" action. These experimental observations lend insight into the PS300 tribological results.

When sliding the PS300 against $\mathrm{Al}_{2} \mathrm{O}_{3}$ at high temperatures, the fluorides readily "wet" the $\mathrm{Al}_{2} \mathrm{O}_{3}$ forming a lubricous film to reduce friction and wear. Figure 6 is an SEM/EDS analysis showing that such transfer occurs. In sliding against Inconel, however, the wear process minimizes the persistence of surface metal oxides inhibiting the growth of a lubricous fluoride transfer film. Thus, against Inconel X-750 pins, high temperature friction and wear is not reduced. In fact, wear is higher. This may be due, in part, to the softening of the superalloy which occurs at these temperatures.

In any case, it is clear that at high temperatures, the high temperature lubricant $\left(\mathrm{BaF}_{2} / \mathrm{CaF}_{2}\right)$ is more functional for the $\mathrm{Al}_{2} \mathrm{O}_{3}$ counterface. This concept is further corroborated by the fact that $\mathrm{Al}_{2} \mathrm{O}_{3}$ readily forms compounds with $\mathrm{BaF}_{2}$ and $\mathrm{CaF}_{2}$ especially at elevated temperatures (ref. 25). In general, transfer film formation and adherence are enhanced by some sort of reaction at the interface (refs. 26 and 17).

\section{CONCLUDING REMARKS}

The tribological characteristics of PS300 presented in this paper dramatically illustrate the important role the counterface plays in determining tribological performance. This concept is often overlooked in solid lubrication perhaps because the chemical reactivity often observed in liquid lubricated systems is not obvious for solid state systems.

For PS300, or other Ag and fluoride lubricated composites, the choice of a counterface must be carefully made taking into consideration use conditions, cost and required tribological properties. If the component to be lubricated will spend most of its operating life at low temperature with only occasional exposure to high temperatures, superalloys, like Inconel X-750, would be a good counterface choice. However, if high temperature performance is paramount, $\mathrm{Al}_{2} \mathrm{O}_{3}$ may be a practical choice despite its brittle nature and, generally, higher manufacturing costs.

Since many advanced engine applications, such as gas turbine bearings, bushings and seals operate predominately at elevated temperatures, $\mathrm{PS} 300$ versus $\mathrm{Al}_{2} \mathrm{O}_{3}$ may be a sliding combination which warrants further study and serious consideration. Furthermore, using the concepts of counterface selection and solid lubricant addition; new composites may be tailored for desirable performance in a wide variety of high temperature tribological applications.

\section{REFERENCES}

1. Cranmer, D.C.: "Ceramic Tribology, Needs and Opportunities," Tribology Transactions, Vol. 31, pp. 164-173, 1988. 
2. DellaCorte, C. and Wood, J.C.: "High Temperature Solid Lubricant Materials for Heavy Duty and Advanced Heat Engines," NASA TM 106570, Sept. 1994, also in M.R. Guyal, Heavy Duty Engines. A Look at the Future, ASME, 1994, NY, pp. 239-253.

3. Sliney, H.E.: "Solid Lubricants," Metals Handbook, vol. 18 Friction, Lubrication, and Wear Technology, pp. 113-122, ASM International 1993.

4. Clauss, F.J.: Solid Lubricants and Self-Lubricating Solids, Academic Press, New York, 1972, pp. 113-137.

5. Fukuda, K., Sato, Y., Sata, T., and Veki, M.: "Wear Properties of SiC Whisker Reinforced Ceramics Against Bearing Steel" in Tribology of Composite Materials, ASM Intl., Metals Park, Ohio, 1990, pp. 323-328.

6. DellaCorte, C. and Edmonds, B.J.: "Preliminary Evaluation of PS300: A New Self-Lubricating High Temperature Composite Coating for Use to $800^{\circ} \mathrm{C}, "$ NASA TM-107056, Nov. 1995.

7. Sliney, H.E.: "A New Chromium Carbide-Based Tribological Coating for Use to $900^{\circ} \mathrm{C}$ with Particular Reference to the Stirling Engine," J. Vac. Sci. Technology, A, Vol. 4, No 6, 1986, pp. 2629-2632.

8. Wagner, R.C. and Sliney, H.E.: "Effects of Silver and Group II Fluorides Addition to Plasma Sprayed Chromium Carbide High Temperature Solid Lubricant for Foil Gas Bearings to $650^{\circ} \mathrm{C}$," NASA TM-86895.

9. Liu, G.H., Robbevalloire, F., Gras, R., and Blovet, J.: "Improvement in Tribological Properties of Chromium Oxide Coating at High Temperature by Solid Lubricants," Wear, 160 (1993) pp. 181-189.

10. Sliney, H.E.: "The Use of Silver in Self-Lubricating Coatings for Extreme Temperatures," ASLE Transactions, Vol. 29, 3, pp. 370-376, 1986.

11. Sliney, H.E., Strom, T.N., and Allen, G.P.: "Fluoride Solid Lubricants for Extreme Temperatures and Corrosive Environments," ASLE Transactions, Vol. 8, No 4, 1965, pp. 307-322.

12. Deadmore, D.L. and Sliney, H.E.: "Hardness of $\mathrm{CaF}_{2}$ and $\mathrm{BaF}_{2}$ Solid Lubricants at 25 to $670{ }^{\circ} \mathrm{C}$," NASA TM-88979, March 1987.

13. Olson, K.M. and Sliney, H.E.: "Additions to Fluoride Lubricant Coatings for Reduction of Low Temperature Friction," NASA TN D-3793, 1967.

14. Erdemir, A., Fenske, G.R., Erck, R.A., and Cheng, C.C.: "Ion-Assisted Deposition of Silver Films on Ceramics for Friction and Wear Control, Lubrication Engineering, 1990, Vol. 46, pp. 23-30.

15. "Amalox 68: Product in Perspective" technical bulletin, Astromet, Inc., Cincinnati, Ohio 1990.

16. DellaCorte, C. and Sliney, H.E.: "Composition Optimization of Self-Lubricating Chromium Carbide-Based Composite Coatings for Use to $760^{\circ} \mathrm{C}, "$ ASLE Transactions, Vol. 30, 1, pp. $77-83$.

17. DellaCorte, C., Pepper S.V., and Honecy, F.S., "Tribological Properties of $\mathrm{Ag} / \mathrm{Ti}$ Films on $\mathrm{Al}_{2} \mathrm{O}_{3}$ Ceramic Substrates," Surface Coatings and Technology, 52, 1992, pp. 31-37.

18. Bowden, F.P. and Tabor, D.: "The Lubrication of Thin Metallic Films and the Action of Bearing Metals," J. Applied Physics, Vol. 14, pp. 141-151, 1943.

19. Skehan, J.W. and Agule, G.J.: "Vacuum Tube Apparatus," U.S. Patent \#2,315,280, March 1943.

20. Trego, L.: "Fasteners for Aerospace Structures", Aerospace Engineering Vol. 11(11), pp 19-23, Nov. 1991. 
21. Sliney, H.E. and Graham, J.W.: "Tribological Properties of Self-Lubricating Fluoride. Metal Composites to $900^{\circ} \mathrm{C}$ - A Review and Some New Developments," ASME J. of Lubrication Technology, July 1975, pp. 500-511.

22. DellaCorte, C. and Sliney, H.E.: "Tribological Properties of PM212: A High Temperature, SelfLubricating, Powder Metallurgy Composite", NASA TM 102355 and Lubrication Engineering, Vol. 47, No. 4, p 289, 1991.

23. Sliney, H.E.: "Lubrication Properties of Ceramic Bonded Calcium Fluoride Coatings on Nickel Base Alloys from 75 to $1900^{\circ} \mathrm{F}, "$ NASA TN D-1190, Feb. 1962.

24. Sliney, H.E.: "Self-Lubricating Composites of Porous Nickel and Nickel-Chromium Alloy Impregnated with $\mathrm{BaF}_{2}-\mathrm{CaF}_{2}$ Eutectic," ASLE Transactions, Vol. 9, 1966, pp. 336-347.

25. Lovin, E.M., Robbins, C.R., and McMurdic, H.F.: "Phase Diagrams for Ceramists, Figure 1673, p. 470, Am. Ceramics Society, 1964, Columbus, Ohio.

26. Poate, J.M., Tu, K.N., and Mayer, J.W.: "Thin Films-Interdiffusion and Reactions," J. Wiley and Sons, 1978.

TABLE I.-COMPOSITION BY WEIGHT AND VOLUME PERCENT OF PS300 AND PS200

\begin{tabular}{|l|c|c|c|c|c|}
\hline \multicolumn{1}{|c|}{ Coating } & Density & \multicolumn{4}{|c|}{ Constituent, wt\% (vol\%) } \\
\hline Designation & $\mathrm{P}, \mathrm{g} / \mathrm{cm}^{3}$ & ${ }^{*} \mathrm{NiCr}-\mathrm{Cr}_{2} \mathrm{O}_{3}$ & $+\mathrm{Ni}-\mathrm{Co}-\mathrm{Cr}_{3} \mathrm{C}_{2}$ & $\mathrm{Ag}$ & $\mathrm{BaF}_{2} / \mathrm{CaF}_{2}$ \\
\hline PS300 & 5.81 & $80(80.3)$ & - & $10(5.5)$ & $10(14.2)$ \\
\hline PS200 & 6.75 & - & $80(77.1)$ & $10(6.4)$ & $10(16.5)$ \\
\hline
\end{tabular}

${ }^{*}$ By wt\% contains $80 \mathrm{Cr}_{2} \mathrm{O}_{3}, 16 \mathrm{Ni}, 4 \mathrm{Cr}$.

${ }^{+}$By wt $\%$ contains $54 \mathrm{Cr}_{3} \mathrm{Cr}_{2}, 28 \mathrm{Ni}, 12 \mathrm{Co}, 2 \mathrm{Mo}, 2 \mathrm{Al}, 1 \mathrm{~B}, 1 \mathrm{Si}$.

TABLE II.-PLASMA SPRAY

PARAMETERS

[Used to apply PS300 coatings]

\begin{tabular}{|c|c|}
\hline Parameter & Value \\
\hline Current & $600 \mathrm{amps}$ \\
\hline Voltage & $30-32$ volts \\
\hline Standoff distance & $8-10 \mathrm{~cm}$ \\
\hline $\begin{array}{l}\text { Argon } \\
\text { Arc gas flow rate }\end{array}$ & $35 \mathrm{sl} / \mathrm{min}$ \\
\hline Powder flow rate & $\approx 1 \mathrm{~kg} / \mathrm{hr}$ \\
\hline Powder gas flow rate & $0.4 \mathrm{~m}^{3} / \mathrm{hr}$ \\
\hline
\end{tabular}


TABLE III.-PROPERTIES OF $\mathrm{Al}_{2} \mathrm{O}_{3}$ MATERIAL TESTED

\begin{tabular}{|l|c|}
\hline \multicolumn{1}{|c|}{ Property } & Value \\
\hline Composition & $\begin{array}{c}99.4 \mathrm{wt} \% \mathrm{Al}_{2} \mathrm{O}_{3} \text { and trace } \\
\mathrm{Fe}, \mathrm{Si}\end{array}$ \\
\hline Density & $3.9 \mathrm{~g} \mathrm{~cm}^{-3}$ \\
\hline Young's modulus & $386 \mathrm{Gpa}^{-2}$ \\
\hline Vickers hardness & $2000 \mathrm{kgf} \mathrm{mm}^{-2}$ \\
\hline Toughness & $4.2 \mathrm{Mpa} \mathrm{m}^{-1 / 2}$ \\
\hline Thermal expansion coefficient & $8.0 \times 10^{-6}{ }^{\circ} \mathrm{C}^{-1}$ \\
\hline Four-point bend strength & $344 \mathrm{Mpa}^{-1}$ \\
\hline Poisson's ratio & 0.23 \\
\hline Thermal conductivity & $22 \mathrm{~W} \mathrm{~m}^{-1}{ }^{\circ} \mathrm{C}^{-1}$ \\
\hline
\end{tabular}

TABLE IV.-FRICTION AND WEAR SUMMARY

[ $1 \mathrm{~m} / \mathrm{s}$ sliding velocity, $4.9 \mathrm{~N}$ load, $30 \mathrm{~min}$ test, air atmosphere at $50 \%$ R.H. at $25^{\circ} \mathrm{C}$ ]

\begin{tabular}{|l|c|c|c|c|c|}
\hline Disk coating & Pin material & Temperature, ${ }^{\circ} \mathrm{C}$ & $\begin{array}{c}\text { Friction } \\
\text { coefficient }\end{array}$ & $\begin{array}{c}\mathrm{K}_{\mathrm{pi}}, \\
\mathrm{mm}^{3} / \mathrm{N}-\mathrm{m}\end{array}$ & $\begin{array}{c}\mathrm{K}_{\text {disk }}, \\
\mathrm{mm}^{3} / \mathrm{N}-\mathrm{m}\end{array}$ \\
\hline PS300 & $\mathbb{I N C X 7 5 0}$ & $25^{\circ} \mathrm{C}$ & $0.23 \pm 0.05$ & $3.9 \pm 0.5 \times 10^{-5}$ & $6.6 \pm 2.5 \times 10^{-5}$ \\
\hline PS300 & $\mathbb{I N C X 7 5 0}$ & $500^{\circ} \mathrm{C}$ & $0.29 \pm 0.04$ & $1.3 \pm 0.3 \times 10^{-5}$ & $3.9 \pm 0.3 \times 10^{-4}$ \\
\hline PS300 & $\mathbb{I N C X 7 5 0}$ & $650^{\circ} \mathrm{C}$ & $0.31 \pm 0.01$ & $3.1 \pm 0.8 \times 10^{-5}$ & $7.1 \pm 1.6 \times 10^{-4}$ \\
\hline PS300 & $\mathrm{Al}_{2} \mathrm{O}_{3}$ & $25^{\circ} \mathrm{C}$ & $0.62 \pm 0.06$ & $3.3 \pm 2.1 \times 10^{-6}$ & $2.3 \pm 0.4 \times 10^{-4}$ \\
\hline PS300 & $\mathrm{Al}_{2} \mathrm{O}_{3}$ & $500^{\circ} \mathrm{C}$ & $0.32 \pm 0.07$ & $2.6 \pm 1.9 \times 10^{-7}$ & $2.5 \pm 1.0 \times 10^{-5}$ \\
\hline PS300 & $\mathrm{Al}_{2} \mathrm{O}_{3}$ & $650^{\circ} \mathrm{C}$ & $0.19 \pm 0.02$ & $2.1 \pm 1.3 \times 10^{-7}$ & $7.8 \pm 2.3 \times 10^{-6}$ \\
\hline
\end{tabular}



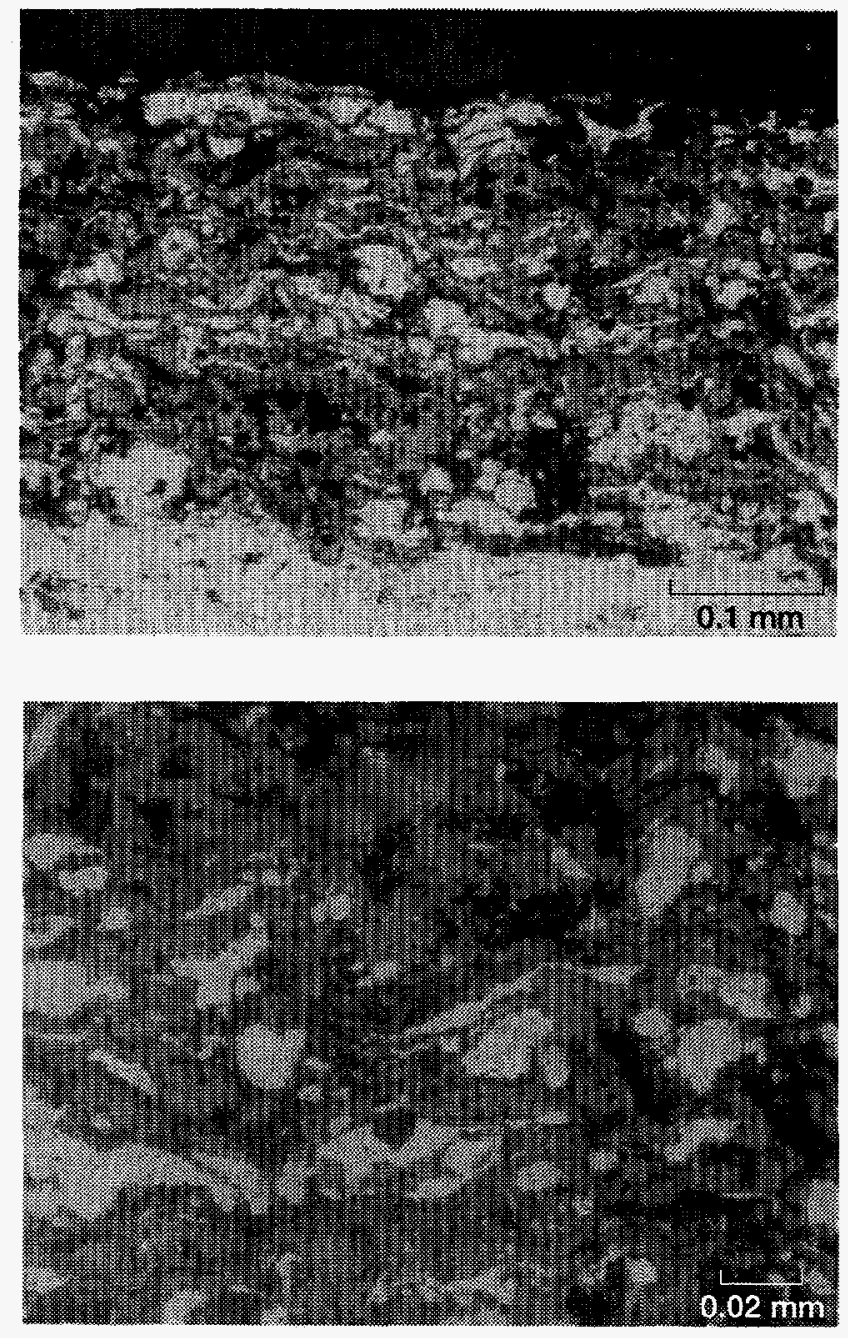

Figure 1.-Cross-sectional optical micrographs of PS300 showing plasma sprayed composite coating structure. 


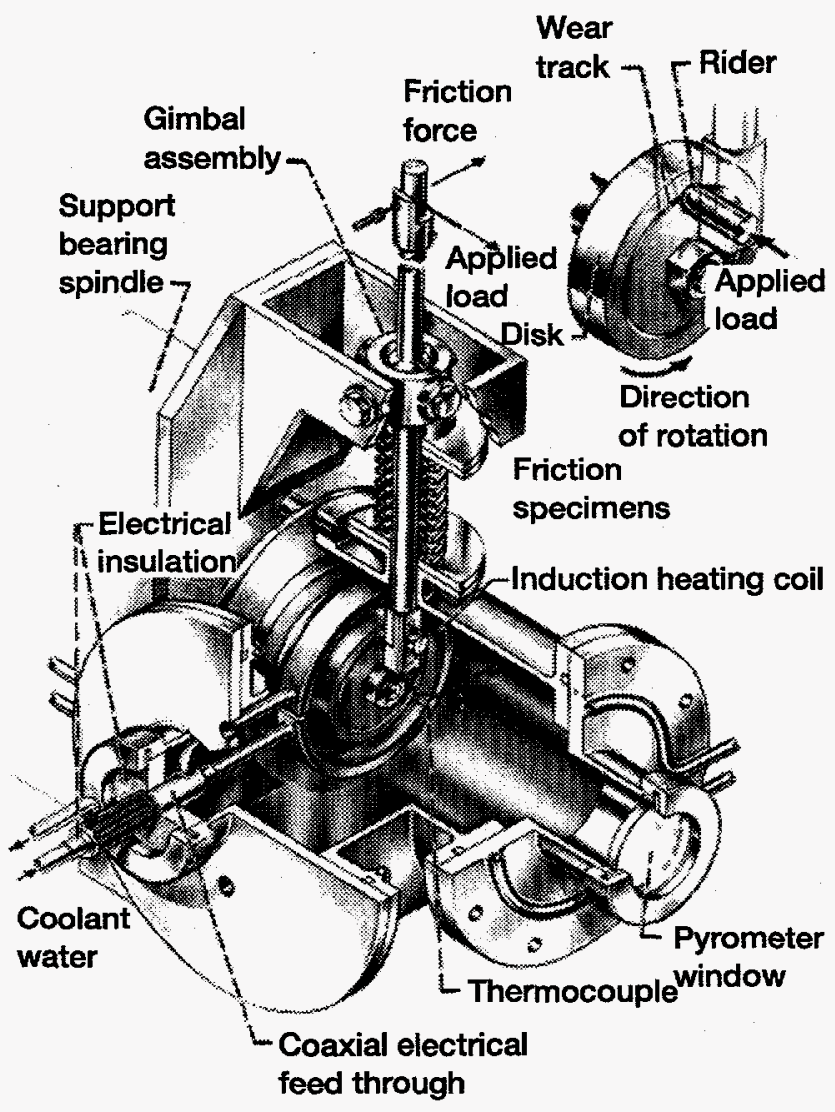

Figure 2.-High temperature friction and wear test rig.

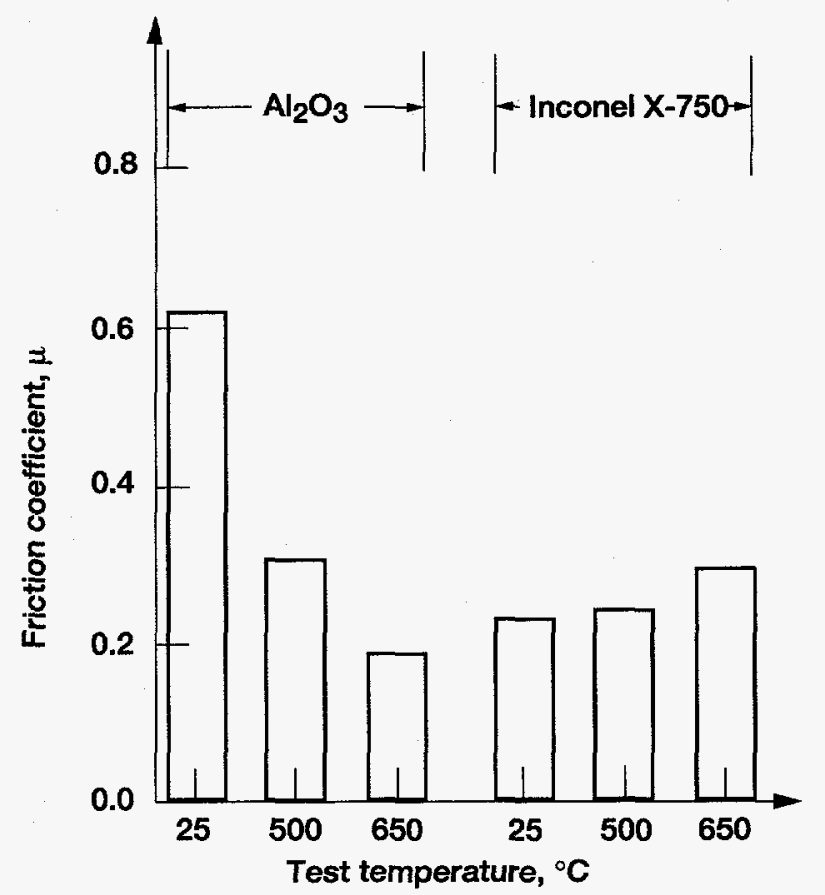

Figure 3.-Friction coefficient, $\mu$, vs. test temperature for both the ceramic $\left(\mathrm{Al}_{2} \mathrm{O}_{3}\right)$ and superalloy (Inconel $X-750)$ pins sliding against PS300 under a 4.9N load, $1 \mathrm{~m} / \mathrm{s}$ sliding velocity, in air. 


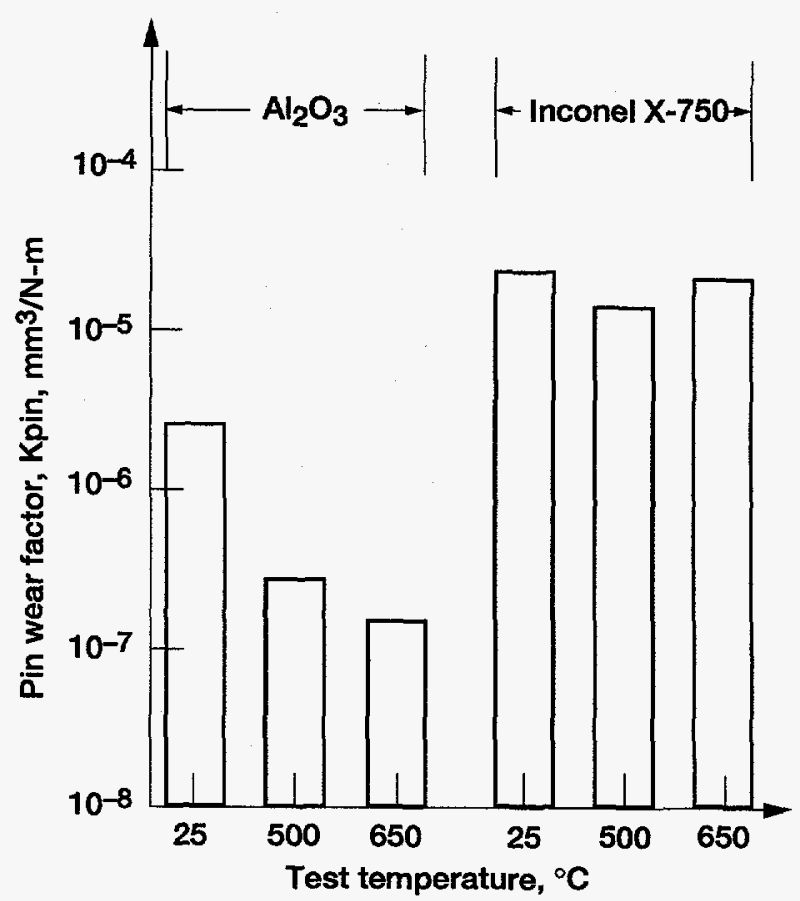

Figure 4.-Pin wear factor, Kpin, vs. test temperature for both the ceramic $\left(\mathrm{Al}_{2} \mathrm{O}_{3}\right)$ and superalloy (Inconel $X-750$ ) pins sliding against PS300 under a 4.9N load, $1 \mathrm{~m} / \mathrm{s}$ sliding velocity, in air.

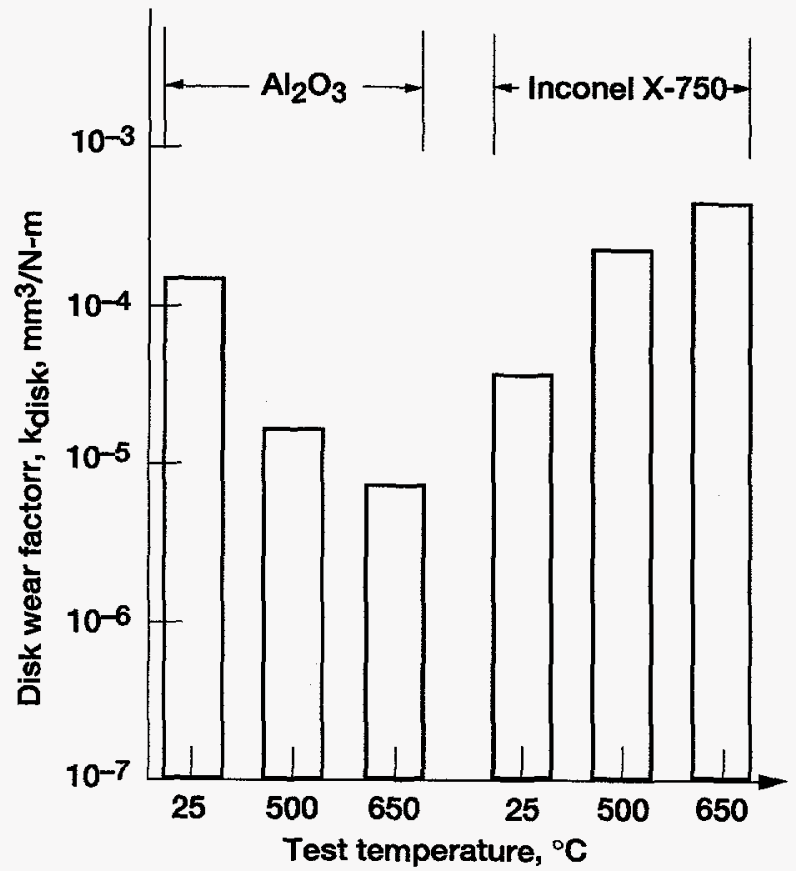

Figure 5.-PS300 coating wear factor, Kdisk vs. test temperature for both the ceramic $\left(\mathrm{Al}_{2} \mathrm{O}_{3}\right)$ and superalloy (Inconel $X-750$ ) pins sliding against PS300 under a $4.9 \mathrm{~N}$ load, $1 \mathrm{~m} / \mathrm{s}$ sliding velocity, in air. 

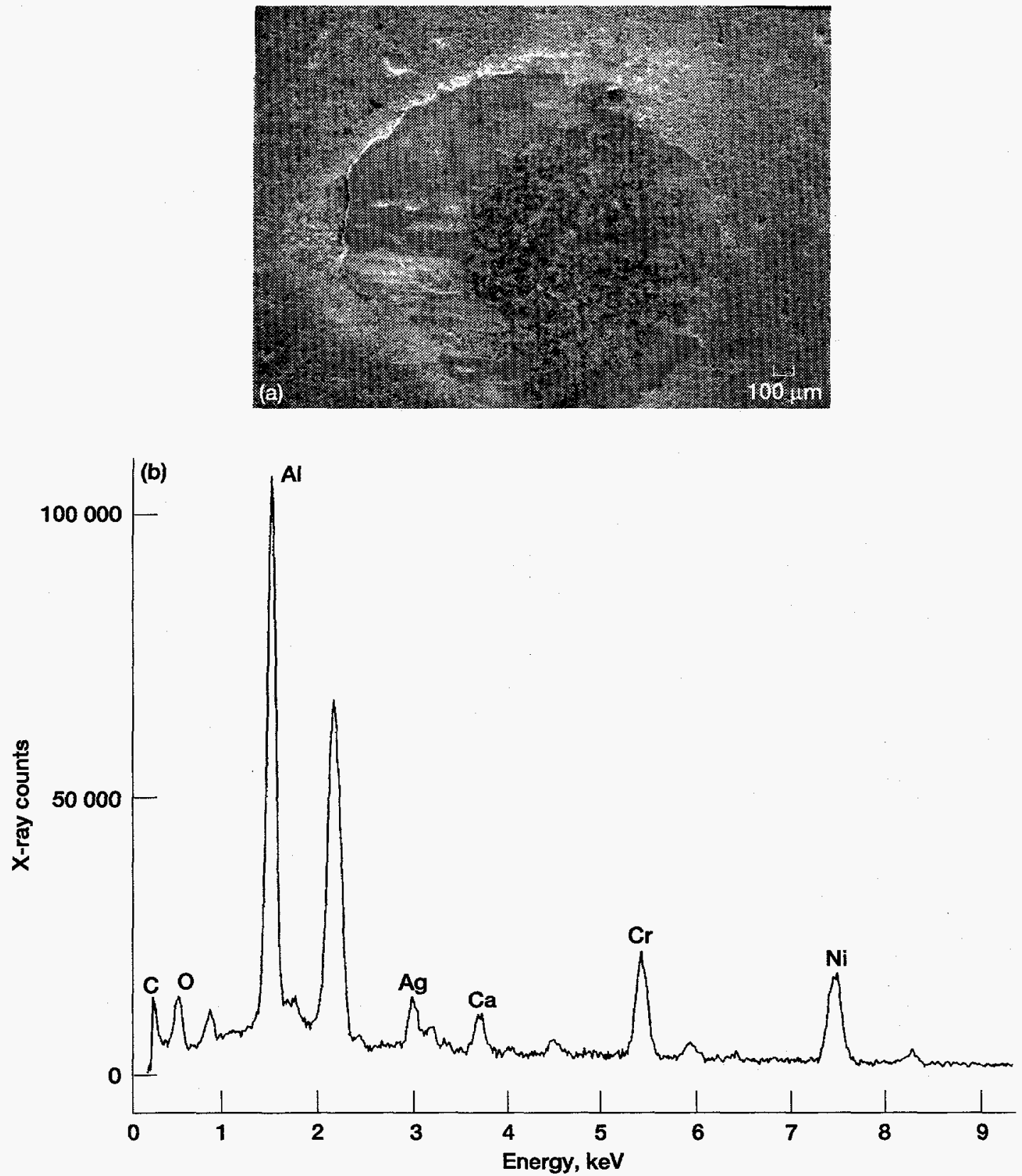

Figure 6.-(a) SEM micrograph of $\mathrm{Al}_{2} \mathrm{O}_{3}$ pin surface after sliding against $\mathrm{PS} 300$ at $650^{\circ} \mathrm{C}, 1 \mathrm{~m} / \mathrm{s}$. (b) Corresponding EDS X-ray spectrum of wear surface showing lubricant $(\mathrm{Ba}, \mathrm{Ca}, \mathrm{Ag})$ peaks, $20 \mathrm{kV}$ accelerating energy. 
Public reporting burden for this collection of information is estimated to average 1 hour per response, including the time for reviewing instructions, searching existing data sources, gathering and maintaining the data needed, and completing and reviewing the collection of information. Send comments regarding this burden estimate or any other aspect of this collection of information, including suggestions for reducing this burden, to Washington Headquarters Services, Directorate for information Operations and Reports, 1215 Jefferson Davis Highway, Suite 1204, Arlington, VA 22202-4302, and to the Office of Management and Budget, Paperwork Reduction Project (0704-0188), Washington, DC 20503.
1. AGENCY USE ONLY (Leave blank) 2. REPORT DATE
April 1996 3. REPORT TYPE AND DATES COVERED
Technical Memorandum

\section{TITLE AND SUBTITLE}

The Effect of Counterface on the Tribological Performance of a High Temperature Solid Lubricant Composite from 25 to $650^{\circ} \mathrm{C}$

\section{AUTHOR(S)}

Christopher DellaCorte

7. PERFORMING ORGANIZATION NAME(S) AND ADDRESS(ES)

National Aeronautics and Space Administration

Lewis Research Center

Cleveland, Ohio 44135-3191

5. FUNDING NUMBERS

9. SPONSORING/MONITORING AGENCY NAME(S) AND ADDRESS(ES)

National Aeronautics and Space Administration

Washington, D.C. 20546-0001

8. PERFORMING ORGANIZATION REPORT NUMBER

$\mathrm{E}-10150$

WU-505-63-5A

WU-778-34-2A

11. SUPPLEMENTARY NOTES

Prepared for the International Conference on Metallurgical Coatings and Thin Films sponsored by the American Vacuum Society, San Diego, California, April 22-26, 1996. Prepared for NASA under Department of Energy Interagency Agreement No. DE-AI01-91CE5036. Responsible person, Christopher DellaCorte, organization code 5140, (216) 433-6056.

12a. DISTRIBUTION/AVALABILITY STATEMENT

Unclassified - Unlimited

Subject Category 23 12b. DISTRIBUTION CODE

DOE Category UC-23

This publication is available from the NASA Center for Aerospace Information, (301) 621-0390.

\section{ABSTRACT (Maximum 200 words)}

The effect of counterface selection on the tribological performance of a $\mathrm{Ag} / \mathrm{BaF}{ }_{2}-\mathrm{CaF}_{2}$ containing composite coating is studied. Ceramic $\left(\mathrm{Al}_{2} \mathrm{O}_{3}\right)$ and metal (Inconel X-750) pins are slid against PS300 (a metal bonded chrome oxide coating with $\mathrm{Ag}$ and $\mathrm{BaF}_{2} / \mathrm{CaF}_{2}$ lubricant additives) in a pin-on-disk tribometer at 25500 and $650^{\circ} \mathrm{C}$. Compared to the ceramic counterface, the metal counterface generally exhibited lower friction and wear at $25^{\circ} \mathrm{C}$ but higher friction and wear at $650^{\circ} \mathrm{C}$. Friction coefficients, for example, for the $\mathrm{Al}_{2} \mathrm{O}_{3} / \mathrm{PS} 300$ combination at $25^{\circ} \mathrm{C}$ were 0.64 compared to 0.23 for the Inconel/PS300 sliding couple. At $650^{\circ} \mathrm{C}$ the ranking was reversed. The $\mathrm{Al}_{2} \mathrm{O}_{3} / \mathrm{PS} 300$ combination gave a friction coefficient of 0.19 while the friction for the metal counterface increased slightly to about 0.3 . Based upon these tribological results and other information found in the literature, it appears that the performance of each counterface/PS300 combination is affected by the ability of the solid lubricant additives to form an adequate transfer film. The effects of surface wettability and tribological compatibility are discussed in relation to the observed tribological results.

\section{SUBJECT TERMS}

Solid lubricant; High temperature; Friction; Wear; Superalloys; Ceramics

15. NUMBER OF PAGES

15

16. PRICE CODE

A03

17. SECURITY CLASSIFICATION OF REPORT

Unclassified

18. SECURITY CLASSIFICATION OF THIS PAGE

Unclassified
19. SECURITY CLASSIFICATION OF ABSTRACT Unclassified 